\title{
Strategic Management Plan for Transnational Organizations
}

\author{
Eungoo Kang ${ }^{1}$, Hee-Joong Hwang ${ }^{2}$
}

Received: April 14, 2018. Revised: April 30, 2018. Accepted: May 5, 2018.

\begin{abstract}
A primary goal of transnationals is to offer their vision for selling products or services so that they are relevant to local cultures. The purpose of this study is to provide a solution for how transnational companies face various environments and how they can utilize and overcome them and survive strategically. This study will present strategic recommendations for transnational organizations. First, transnational organizations should identify the core areas where organizational can invest or allocate its precious resources to get full advantage of the attractive opportunities form the market and focus on building strong networks with the key stakeholders. Second, they should manage the knowledge flows and provide strategic direction in cooperative venture for the long term successful future and ensure that every department has an effective coordination with other departments in order to bring about the organizational change. Lastly, they should overcome the challenges managers face in a transnational business environment when companies expand their operations into international markets. The managers need to assess the organization's strengths and weaknesses and evaluate different forces which are present in the external environment. And then, Managers have to ensure that the company has sufficient resources, core competencies and capabilities.
\end{abstract}

Keywords: Transnational Organization, Corporate Social Responsibility (CSR), Strategic Management.

JEL Classification code: D21, D23, M13, M14.

\section{Introduction}

The globalization which is a derivative of innovation and technology is based on the process of international relocation by the efforts of transnational organizations. That implies there is little doubt that transnational companies concentrate on engaging in the displacement production to other countries. Thus, those companies perform the role of "driver" for developing of global innovation (Dnishev \& Alzhanova, 2016) and that is why the share of transnational companies in the global financing research and development (R\&D) is almost $50 \%$ and world production percentage is even over 60\% (Markov, 2015). Further investigation shows that General Electric, the mammoth American conglomerate, was revealed to possess the most

1 First Author, Doctoral student in Business Administration Program, Saint Mary's University of Minnesota, 2500 Park Ave Minneapolis, MN., US.

2 Corresponding Author, Professor, Department of International Trade, Korea National Open University, Korea. [Postal Address: 86 (Dongsoong-dong), Daehak-ro, Jongro-gu, Seoul, \#03087, Korea] E-mail: ygodson@knou.ac.kr assets abroad (over $\$ 500$ billion worth) among all nonfinancial firms across the world. Of its total assets, its foreign assets account for $70 \%$ of them. Prior research has also points out that 17 of the 100 companies that hold the most foreign assets have over $90 \%$ of their assets across borders. About $\$ 5$ trillion are being stockpiled by transnational companies in cash. Foreign direct investment, then, could surge as a result (Pries, 2013; Bennett \& Sharpe, 2014).

Throughout the past 20 years, the importance of transnational corporations, generally understood as emerging markets, transition economies and less developed countries, has been rising. However, increased proliferation of globalization has brought attention to several new issues related to transnational firms. While initially host governments were hesitant about those perceived as exploiters, developing nations have changed their attitudes toward transnationals, welcoming these companies and understanding foreign direct investment to be important to development. Through bolstering economic growth and assisting social development, transnational firms can take on pivotal roles in development (Andersson, Forsgren, \& Holm, 2007). Former research has already suggested that 
firms can achieve competitive advantages through business models with appropriate corporate governance mechanisms and innovative strategies (Armstrong, Guay, \& Weber, 2010) in emerging economies as a result of multinational firms' low cost approach to monopolistic competition over local firms (Brunninge, Nordqvist, \& Wiklund, 2007). Through the usage of tacit knowledge of the board of directors, standards, procedures, and strong corporate management mechanisms assist in gaining market share in business models. With the goal of decreasing agency conflict, this is strongly reflected in their managerial activities' strategic plans.

Regarding this emerging situation, this study will present comprehensive strategic recommendations to handle various circumstances for transnational organizations, answering important questions related to the transnational business environment difficulties, stating (1) the sustainability and corporate social responsibility (CSR) attitude of firms; (2) the flow of goods, resources, and information while cultivating a coordination system within transnational organizations; and (3) the management of the boundary, management of knowledge flows, and strategic direction in cooperative ventures.

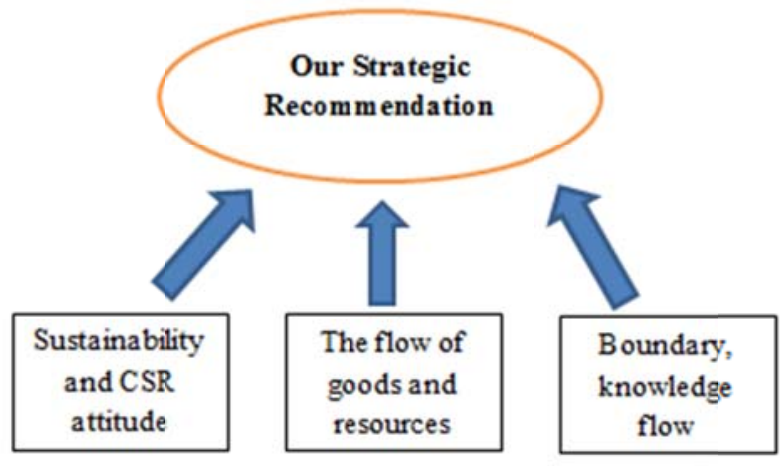

Figure 1. Essential components for strategic recommendation

\section{Research Gap in the Literature}

Because there is scant research available for guidance in regard to what organizational elements should be important to achieve successful international relocation, the present study will be able to add insight into the literature by elaborating on the comprehensive strategic implementations for transnational organizations. Much multinational business strategy literature tends to focus on components for only three options in terms of international value creation in response to regional differences such as adaptation, aggregation, and arbitrage. Numerous researchers have already explored those three options, and transnational companies needing conduct standardization or localization strategy for their products have focused on them.

First, literature has mentioned that still leading to some economies of scale, coping with cross-country differences by partially modifying a basic template by local changes is implied by an adaptation strategy. Ultimately resulting in regional scale economies and a review the subsidiaries' functions, production relocations to the most efficient subunits are usually implied by regional adaptations financed by firm-level investments. Product variations, a focus on certain customer segments, externalization by franchising, product designs on the basis of platforms, or innovations from existing business model are all further examples of possible adaptation strategy. As a precursor in the debate, Levitt contended that corporations had to disregard superficial regional and national boundaries in learning to operate in one great global market and move from customizing products to provide universally standardized products had to be made for well managed companies (Averchenkova, Crick, Kocornik-Mina, Leck, \& Surminski, 2015; Militaru \& Zanfir, 2014; Heinecke, 2011; Ghemawat, 2008; Ghemawat \& Ghadar, 2006; Rugman 2005b; Levitt, 1983).

Second, extant literature has also stated that exploiting the similarities across several countries, by overcoming their differences somehow and consequentially, reaping increasing returns to scale is what is involved in the strategic dimension aggregation. Given that competitive advantages of transnational companies can be deployed across national borders, regional aggregation occurs only in a limited geographic region. Through standardization of products or services, transnational companies can attain aggregation advantages within the region. However, it is argued that a standardized approach can be impossible because of too much dissimilarity between countries and too many restrictions in different markets. Therefore, the method international managers use in this respect may need to be tailored to each component of the business system and marketing program. Marketing the same product under different brand names in different countries may be needed to be done by the manufacturer. Being more easily controlled and monitored are the result of standardization because the same product and advertising strategies are used (Haron, 2016; Heinecke, 2011; Ghemawat, 2008; Ghemawat, 2007a; Rugman, 2005; Ghemawat, 2003; Narayandas, Quelch, \& Swartz, 2000; Aaker \& Joachimsthaler, 1999; Aaker \& Shansby, 1982).

Last, our investigation of literature review on international business strategy showed that the exploitation of differences among countries, such as different absolute cost levels is what is involved in strategic dimension arbitrage. The advantages of regional arbitrage could include an inter- 
regional division of the supply chain along distinct locations and are realized mostly across regions. For instance, call centers in India, factories in Malaysia, and retail shops in Japan are all examples of this. By adding new dimensions of product or service, regionalization impacts the multidimensionality of transnational organizations. Prior studies pointed out that transnational companies establish complicated administrative structures more and more and expand their centralized plans to new geographical areas to corroborate various business activities (Heinecke, 2011; Ghemawat, 2007a; Pearce \& Papanastassiou, 2006; Enright 2005a; Ghemawat, 2003; Hennart, 2000; Doz \& Prahalad, 1991; Williams, 1967).

Table 1. The prevailing typology of multinational business strategy

\begin{tabular}{|c|c|}
\hline Typology & Proposed view \\
\hline Adaptation & $\begin{array}{l}\text { Ultimately resulting in regional scale } \\
\text { economies and a review the subsidiaries' } \\
\text { functions, production relocations to the most } \\
\text { efficient subunits are usually implied by } \\
\text { regional adaptations financed by firm-level } \\
\text { investments. } \\
\text { Ex) Product variations, a focus on certain } \\
\text { customer segments, externalization by } \\
\text { franchising, product designs on the basis of } \\
\text { platforms, or innovations from existing } \\
\text { business model. }\end{array}$ \\
\hline Aggregation & $\begin{array}{l}\text { Exploiting the similarities across several } \\
\text { countries, by overcoming their differences } \\
\text { somehow and consequentially, reaping } \\
\text { increasing returns to scale is what is } \\
\text { involved in the strategic dimension } \\
\text { aggregation. } \\
\text { Ex) Marketing strategy of the same product } \\
\text { under different brand names in different } \\
\text { countries. }\end{array}$ \\
\hline Arbitrage & $\begin{array}{l}\text { The exploitation of differences among } \\
\text { countries, such as different absolute cost } \\
\text { levels is what is involved in strategic } \\
\text { dimension arbitrage. Arbitrage could include } \\
\text { an inter-regional division of the supply chain, } \\
\text { adding new dimensions of product or } \\
\text { service. } \\
\text { Ex) Call centers in India, factories in } \\
\text { Malaysia, and retail shops in Japan. }\end{array}$ \\
\hline
\end{tabular}

In sum, concentrating on only the three bodies in the literature ultimately, the existing research regarding transnational organizations as a way to improve organizational performance in different countries predominates just theoretical viewpoints and offers limited approaches to practitioners. Thus, guidance with the use of practical strategic approach for transnational companies seems particularly lacking in the literature. As a result, that would be quite reasonable that this study investigates more inclusive approach for managers to provide robust directions, stating the flow of goods, resources and knowledge, and the management of the boundary. The present study departs from elaborating goal and vision for transnational organizations before taking a close look at detailed comprehensive implementations.

\section{Strategic Management for Transnational Companies}

\subsection{The Suggestion of Goal, Vision for Transnational Organizations}

A primary goal of transnationals is to offer their vision for selling products or services so that they are relevant to local cultures, as discussed by Kentor (2015). While a miss results in lingering mistakes and misunderstandings, a hit leads to revenue streams and successful partnerships. Transnational business is unique in that they confront cultural, linguistic, religious, and ethnic bridge complexities while sustaining a vision created in the boardroom. A transnational company has an objective once the proper opportunities for new sites are identified. The goal is to sell products or services in a manner that the local population can relate to and choose to purchase them across time zones in various locations. While a desirable goal, arduous tasks await. Not only does research need to be conducted, but forming trust and ground investigation are also necessary.

\section{Strategic Management for Transnational Companies}

\subsection{The Flow of Goods, Resources, and Information while Developing a Coordination System in a Transnational Organization}

Meeting local needs and growing the company's bottom line are both essential factors in marketing the vision and mission statement for a transnational corporation. Without the necessary adaptation of vision and products or services to local tastes, failure is imminent. Another concern is not spoiling the product through the undue influence of the local culture. Moreover, according the Kentor (2015), political and economic obstacles will exist. The doing and redoing of advertisements must happen as well. The exploration of regional opportunities in nearby regions (cities or countries) leads to new chances and added difficulties. In new contexts, asking for and receiving back a transfer of values is what a smart multinational firm does. Such influences can carry risk because of how they can affect the brand. 
However, as opposed to standardization, localization of the product is the goal here. Instead of being perceived as a foreign product, the product must seem local. That said, an unhealthy amount of localization can result in business failure due to the destruction of a product, as backed by studies. Proper listening, finding the right partners, and promoting new key leaders internally are keys to learning from locals to influence the brand and service offerings. To create a truly global brand, nothing less than a local partnership is vital (Pries, 2013; Bennett \& Sharpe, 2014; Andersson et al., 2007).

To most effectively and profitably compete with their industry rivals, transnational companies must establish strong networks with their customers, supply chain members, and strategic business partners in this competitive and fast-paced business environment. The most substantial issue here is finding the core areas in which the firms can allocate or invest their limited resources in order to wholly take advantage of the market's attractive opportunities. Innovation is the result when these companies are able to establish strong business relationships with their key stakeholders. In stiff competition or a highly insecure business situation, innovation is one of the best achievements for an organization. The result of extensive research or development in one specific area in such a way that it does not impact the normal routine of operations in other areas in referred to as innovation. A competitive position in one's industry is achieved through successfully bringing innovation into one's system, products, or processes. According to researchers, though discontinuous innovation is short term, it has direct impact on the market structures and consumer preferences in an industry (Frenz \& letto-Gillies, 2009; Birkinshaw et al., 2007; Bennett \& Sharpe, 2014; Andersson et al., 2007).

\subsubsection{Barriers in innovation}

Studies also reveal that several barriers and obstacles that stand in the way of successful innovation integration must be known by managers. First, managers must be cognizant of the organization's level of sufficient goods, resources, and information needed to create change in a system. Second, areas requiring the greatest focus of the organization must be identified by managers. Human resources, informational resources, and physical resources are some of the most crucial factors for innovation. The types of challenges that will need to be overcome during the innovation process must be known by the managers (Birkinshaw, et al., 2007; Bennett \& Sharpe, 2014).

\subsubsection{Building strong networks}

Birkinshaw et al. (2007) have put great focus on developing strong networks with the key stakeholders. This can helpful and offer support for an organization in a discontinuous innovation process. Instead of looking to create new relationships and networks, they believe strengthening existing relationships with key stakeholders and their satisfaction with performance and achievements should be prioritized. A multitude of discontinuous innovation techniques to boost competitiveness in an industry are suggested in the studies. Building and maintaining strong relationships with the customers is the first suggestion. This can be achieved through the manufacturing of products best suited to the customers' needs and expectations. Searching for long term, strategic partners in the industry is the second suggest technique. For this sort of a partnership, it must be assessed whether or not the goods, resources, and information of each organization will support the strengths and capabilities of the other. Entering into technological collaboration with the equally strong and competent firms in related industries, opening innovation networks, or making cross-industry alliances are also possible options to pursue. By clearly showing the significance of an organization's capabilities, resources, and networks in bringing innovation in their system - a technique to bolster position and competitiveness in the industry, Birkinshaw et al. (2007) have supported the statement of Bartlett \& Beamish. In both general business processes and strategic ventures,

\subsection{Managing the Boundary, Managing the Knowledge Flows, and Providing Strategic Direction in Cooperative Venture}

\subsubsection{Ambidexterity}

Ambidexterity has been growing in importance. Instead of concentrating on short term profitability or performance, transnational companies have turned their attention to bolstering their market position for long term industry success and competitiveness. Thus, comprehension of the critical roles of adaptability and alignment in their strategic business units and their processes is essential. As well as on gaining the maximum advantage from their own strengths and competencies, organizations must focus on adapting to change in their strategic endeavors (Mom, Van Den Bosch, \& Volberda, 2009).

\subsubsection{Access to informational resources}

First of all, ensuring equitable and efficient accessibility to the informational resources for all their business units comes first. The responsibility lies largely with the top of management in this case - they must create organizational 
changed in a structured manner by establishing effective coordination between departments. The second prerogative is for organizations to identify new methods of value creation for the customers. Introduction of more innovative or advanced products and improvement on existing products are two ways through which to achieve this. In addition, they have to provide value-added services to their customers in order to gain a competitive edge over their industry rivals.

\subsubsection{Structural ambidexterity and contextual ambidexterity}

Further, to gain some competitive advantage over industry rivals, they must offer customers value-added services. Organizations must put focus on both Structural Ambidexterity and Contextual Ambidexterity in their business proceedings to effectively conduct their collaborative ventures. When team work is needed, for instance, employees are directed to allocate their resources, efforts, and time between adaptability-focused and alignment-focused activities. Employees have full autonomy in making small scale decisions related to their day to day job responsibilities and duties. When employees are able to share information and assist one another, the nature of their jobs become comparatively more flexible. (Birkinshaw \& Gibson, 2004; Mom et al., 2009; Rothaermel and Alexandre, 2009). Conversely, when employees are separated into two different groups, one for Alignment-focused activities and the other for adaptability-focused activities, they lose autonomy in making the aforementioned decisions. In this case, the only authority able to direct, supervise, and lead the groups in their activities is the top level of management. As a result, responsibilities and tasks are clearly defined and communicated to all members of the organization, because Alignment-focused activities and adaptabilityfocused activities are managed separately. However, this only occurs if and when organizational members are specialists in their specific professional fields. Birkinshaw and Gibson (2004) assert that organizations, in their management of collaborative ventures, must choose between Alignment-focused activities and adaptabilityfocused activities. More clearly, if a new venture is attempting to accomplish objectives through teamwork and brainstorming, Contextual Ambidexterity has to be chosen. Conversely, Structural Ambidexterity is the choice if top management directs and assigns responsibilities without considering merging these activities. While Birkinshaw and Gibson (2004) put more emphasis on organizational structure and workflow activities, Bartlett \& Beamish focus on the significance of knowledge flow. Despite this difference, both groups strongly emphasize strategic direction which is critical when a collaborative venture is opted into by an organization.

\subsection{The Challenges Managers face in a Transnational Business Environment and CSR}

Business organizations enter a broader and highly complex business environment when they spread their operations into international markets. In a transnational environment the resources, capabilities, and strengths which were enough to compete in the local environment become insufficient. To regulate their organization's operations in an efficient manner, business managers must develop and improve their interpersonal skills and professional competencies in a challenging and complex multinational environment. It must be recognized by management that the competitive positioning and strength of their firm in the local environment will not be enough for competition in an international setting.

\subsubsection{Stronger and more complex environmental forces}

According to studies by Ghoshal and Bartlett (1986), Aragon-Correa and Sharma (2003), and Grant (2015), sensing the additional effects resulting from comparatively stronger environmental forces is the first challenge managers face when entering a transnational environment. They assert that management must be able to analyze the new market structures, competitive forces, and consumer needs with strong analytical skills in the transnational business setting. It is necessary to have the ability to gather and analyze data that clarifies new industry patterns. Further, it managers need to be able to strategize according to such patterns in order to compete profitably.

\subsubsection{Corporate Strategies and Responsibilities (CSR)}

An organization must define new strategic objectives and design strategies to achieve these targets when opting to enter an international market. Therefore, an organization's top management will become more prone to complex and intensive challenges of the new markets. A strong level of legitimacy and supervision of their organization's operations and the performance of its workforce must be maintained by the top-level management for good performance in these markets. Due to the greater intensity of external forces, they should have greater responsibilities despite enjoying a larger range of control in the international operations of their organization. 


\subsubsection{An example - Procter \& Gamble}

This argument is supported by Ghoshal and Bartlett (1986), who give the example of Procter and Gamble managers who failed to present expected results due to undermining their roles in an international operation. However, the managers ultimately succeeded in launching a new product in the European market by learning from their new environment. To overcome the issues and challenges of the new international market, the organization's top management believed it managers needed to take on greater responsibilities. By showing full confidence in the performance and effort of its managers, it became a spring of encouragement for them.

\subsubsection{Issues and challenges in transnational environment}

First, an important part of its internal environment, the organization's strengths and weaknesses must be evaluated by the managers. Next, various forces present in the external environment must be assessed. Following the analysis of both these environments, management must secure sufficient resources, core competencies, and capabilities which can enable the organization to confront the competitive pressures and manage the broader environment in an efficient manner. Extensive market exposure and the ability to learn and develop in a new environment are needed for managers to analyze these environment and organizational capabilities. Any local work setting knowledge and experience of the managers will only be able to assist them in recognizing the international market's potential environmental forces. Managing these forces in order to penetrate and compete profitably in the new markets will be the real challenge.

\subsubsection{Competitiveness in the long run}

If organizations desire securing sustainable future in their respective industry, Porter and Kramer (2011) argue that they must think from a strategic perspective. They should work to bolster their competitive position in the long run, rather than concentrating on short term financial performance. With this purpose in mind, operational or financial performance cannot be solely relied on; in fact, they must concentrate on the equally important factors of value creation and corporate social responsibility. Thus, the importance of value creation and social welfare efforts regardless of their organization's scale and scope of operations must be understood by managers.

\subsubsection{Corporate social responsibility (CSR)}

When organizations begin to prioritize economic benefits instead of social and environmental concerns, according to Porter and Kramer (2011), they fail in their industry. Despite significantly increasing the operational costs of organizations, social welfare and corporate social responsibility projects are becoming more important sources of competitive advantage as time passes. Managers need to devote resources to social welfare projects to prove that their organization is a socially and environmentally responsible business entity (Porter \& Kramer, 2011). As discussed and argued by the claims of Porter \& Kramer (2011) and Bartlett and Ghoshal (1986), teams of managers who have requisite knowledge, skills, and competencies that can add to their effective operation and competition in a transnational business environment must be developed by organizations.

\subsubsection{Changes in the global economy}

According to Prahalad and Hammond's article, "Serving the World's Poor, profitably (2002)," the global economy has seen a multitude of changes during the last few decades as a result of population growth and urbanization, scientific and technological advancements, and natural calamities. Negative factors like terrorism and bad economic conditions like deflation, recession, financial crisis, etc. have made surviving simply off of financial performance a difficult task for business organizations. Carrying out and sponsoring social welfare activities for the people in need of the country in which they operate is necessary on top of producing good returns for the stakeholders (Prahalad \& Hammond, 2002).

\subsubsection{Corporate social responsibility (CSR) and sustainability in multinational perspective}

In the multinational context, the expectations of investment in sustainability and corporate social responsibility efforts increase up to a large extent. The expectations for sustainability and corporate social responsibility investment efforts increase significantly when in a multinational context. The organizations which operate at the local level are limited to the geographical boundaries of one market or maximum to a single country. A single country or one market's geographical boundaries usually limit the operations of organizations at the local level. In contrast, social welfare in every area of operating is expected from organizations that operate in multiples countries or regions. In fact, such organizations are met with more vilification and criticism by the international community when more interest toward their economic benefits are 
shown rather than toward their social welfare activities (Prahalad \& Hammond, 2002).

\subsubsection{What managers need to do?}

First, the social, cultural, demographical, economic, and political positions of the community in which they are operating or planning on operating as a part of their business expansion strategy must be understood. Following the analysis of these positions, the managers can become cognizant of their community's daily challenges. Then, off of this analysis, they can begin to offer solutions to these challenges by initiating projects on behalf of their organization. It is largely accepted that efforts to be a socially responsible corporate entity results in positive effects on the stakeholder relations and public perception of the organizations.

\subsubsection{Risks in the transnational environment and the sense of Corporate social responsibility}

In contrast to local environments, transnational environments present some extra risks and issues for business organizations. The organizations' capabilities to effectively and profitably compete are directly impacted by these risks. Therefore, such risks must be considered when organizations choose to invest in corporate social responsibility projects. The behavior of general public, support by the local and international regulatory authorities, legal considerations, technological environment of the target countries, etc. are some of the major risks associated with international expansion and more specifically with the CSR and sustainability projects (Prahalad \& Hammond, 2002).

\subsubsection{Ethical considerations}

Business ethics is among the most critical deliberations in international expansion and CSR projects. It has a prominent impact on the manner in which organizations make decisions and strategize for competition in a new environment. While on international assignments or strategic projects, Donaldson (1996) believes that it is equally important for business organizations to operate in the most ethical and legally proper manner possible. Some universally accepted business and personal ethics exist in the business world. Organizations that do not stick to the legal and ethical norms of its targets countries risk their success and sustainability in those regions. Such organizations will be at the mercy of the target country's criticism from the regulatory authorities and general public in addition to strong antagonism from the international community

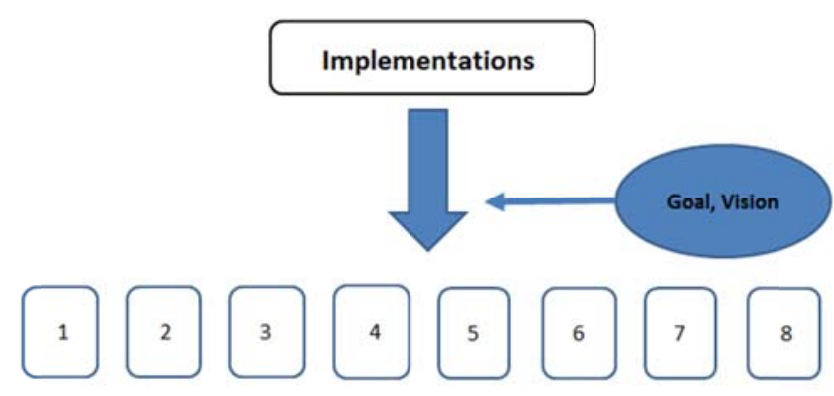

*1 - Innovation *2 - Strong networks with the key stakeholders. *3Effective coordination between all departments. *4 - Full authority for employees to make small scale decisions. ${ }^{\star} 5$ - Assessing the organization's strengths and weaknesses. *6 - Managers' analytical skills for new markets. *7 - Gathering data about new industry partners. ${ }^{*} 8$ - Focusing on CSR. ${ }^{*} 9$. Understanding cultural, political situations for new markets.

Figure 2. Subset elements of strategic implementation

\section{Conclusion and Implication}

According to numerous studies (Pries, 2013; Bennett \& Sharpe, 2014; Andersson, Forsgren \& Holm, 2007; Kentor, 2015; Frenz \& letto-Gillies, 2009; Birkinshaw, Bessant, \& Delbridge, 2007; Mom, Van Den Bosch, \& Volberda, 2009; Birkinshaw \& Gibson, 2004; Mom et al., 2009; Rothaermel \& Alexandre, 2009; Ghoshal \& Bartlett, 1986; Aragon-Correa \& Sharma,2003; Porter \& Kramer, 2011; Prahalad \& Hammond, 2002), the present study recommends transnational organizations should consider the following strategic plans and implementations (see the figure 1 for more details). First, transnational organizations should identify the core areas where organizational can invest or allocate its precious resources to get full advantage of the attractive opportunities form the market and focus on building strong networks with the key stakeholders which can assist the organization in discontinuous innovation process (strong relationship with customers and strategic partners in its industry.

Second, they should manage the knowledge flows and provide strategic direction in cooperative venture for the long term successful future and ensure that every department has an effective coordination with other departments in order to bring about the organizational change. Moreover, employees should be given full authority to make small scale decisions related to their day to day job activities and tasks and the nature of job should be made 
comparatively flexible where employees can share information and help each other in their job responsibilities.

Lastly, they should overcome the challenges managers face in a transnational business environment when companies expand their operations into international markets. To resolve the challenges, the managers need to assess the organization's strengths and weaknesses and evaluate different forces which are present in the external environment. And then, Managers have to ensure that the company has sufficient resources, core competencies and capabilities.

Furthermore, managers must have strong analytical skills to analyze the new market structures, competitive forces, and customer needs to sense the extra impacts from comparatively stronger environmental forces and must be able to gather and analyze data which can help them in understanding the new industry patterns and strategize to compete these patterns. Managers cannot just rely on their operational or financial performance- an equally important area which needs be focused is the Corporate Social Responsibility and need to understand the social, cultural, demographical, economic and political situation of the community in which they are going to operate as a part of business expansion strategy (getting aware of the problems and issues which community members are facing in their daily life).

We contend that transnational organizations seeking international strategic plans should foster our suggested implementation for transnational organizations. In regard to practitioners, the present study insists that the international business environment, such as CSR attitude, the flow of goods, the management of the boundary, and the management of knowledge flows should not be excluded in the alignment of firm strategy to achieve their goals. Through the extension of our understanding of the strategic management for transnational organizations, and thus, providing more robust comprehensive approach including nine implementations within three strategic plans, we contribute to the literature in international relations and business practices. These constructs have not been connected for a review of contingency fit research in the field of international strategy in any prior research to our knowledge. As the present study suggests to identify if they may be generalizable to the extensive spectrum of transnational organizations or if there are specific examples that implementations might fail, forthcoming research may empirically test the relationship between strategic plans and implementation.
Table 2. Detailed implementations for transnational organizations

\begin{tabular}{|c|c|}
\hline $\begin{array}{l}\text { Strategic Plan } \\
\text { (Step 1) }\end{array}$ & $\Longrightarrow \quad \begin{array}{c}\text { Implementation } \\
\text { (Step 2) }\end{array}$ \\
\hline $\begin{array}{l}\text { *Identify the core } \\
\text { areas where } \\
\text { organizational can } \\
\text { invest or allocate its } \\
\text { precious resources } \\
\text { to get full advantage } \\
\text { of the attractive } \\
\text { opportunities form } \\
\text { the market. }\end{array}$ & $\begin{array}{l}\text { *Innovation (to make in the presence } \\
\text { of a stiff competition or highly } \\
\text { uncertain business environment) } \\
\text { *Focus on building strong networks } \\
\text { with the key stakeholders which can } \\
\text { assist the organization in } \\
\text { discontinuous innovation process } \\
\text { (strong relationship with customers } \\
\text { and strategic partners in its industry. }\end{array}$ \\
\hline $\begin{array}{l}\text { *Manage the } \\
\text { knowledge flows and } \\
\text { provide strategic } \\
\text { direction in } \\
\text { cooperative venture } \\
\text { for the long term } \\
\text { successful future. }\end{array}$ & $\begin{array}{l}\text { *Ensure that every department has an } \\
\text { effective coordination with other } \\
\text { departments in order to bring about } \\
\text { the organizational change. } \\
\text { *Employees are given full authority to } \\
\text { make small scale decisions related } \\
\text { to their day to day job activities and } \\
\text { tasks. The nature of job is made } \\
\text { comparatively flexible where } \\
\text { employees can share information } \\
\text { and help each other in their job } \\
\text { responsibilities. }\end{array}$ \\
\hline $\begin{array}{l}\text { *Overcome the } \\
\text { challenges } \\
\text { managers face in a } \\
\text { transnational } \\
\text { business } \\
\text { environment when } \\
\text { companies expand } \\
\text { their operations into } \\
\text { international } \\
\text { markets. }\end{array}$ & $\begin{array}{l}\text { *The managers need to assess the } \\
\text { organization's strengths and } \\
\text { weaknesses and evaluate different } \\
\text { forces which are present in the } \\
\text { external environment. And then, } \\
\text { managers have to ensure that the } \\
\text { company has sufficient resources, } \\
\text { core competencies and capabilities. } \\
\text { *Managers must have strong } \\
\text { analytical skills to analyze the new } \\
\text { market structures, competitive } \\
\text { forces, and customer needs to } \\
\text { sense the extra impacts from } \\
\text { comparatively stronger } \\
\text { environmental forces. } \\
\text { *Managers must be able to gather } \\
\text { and analyze data which can help } \\
\text { them in understanding the new } \\
\text { industry patterns and strategize to } \\
\text { compete these patterns. } \\
\text { *Managers cannot just rely on their } \\
\text { operational or financial performance- } \\
\text { an equally important area which } \\
\text { needs be focused is the Corporate } \\
\text { Social Responsibility } \\
\text { *Managers need to understand the } \\
\text { social, cultural, demographical, } \\
\text { economic and political situation of } \\
\text { the community in which they are } \\
\text { going to operate as a part of } \\
\text { business expansion strategy (getting } \\
\text { aware of the problems and issues } \\
\text { which community members are } \\
\text { facing in their daily life). }\end{array}$ \\
\hline
\end{tabular}




\section{References}

Aaker, D. A., \& Joachimsthaler, E. (1999). The Lure of Global Branding. Harvard Business Review, 77(6), 137-144.

Aaker, D. A., \& Shansby, J. G. (1982). Positioning Your Product. Business Horizons, 25(3), 56-62.

Andersson, U., Forsgren, M., \& Holm, U. (2007). Balancing subsidiary influence in the federative MNC: A business network view. Journal of International Business Studies, 38(5), 802-818.

Aragon-Correa, J. A., \& Sharma, S. (2003). A contingent resource-based view of proactive corporate environmental strategy. Academy of Management Review, 28(1), 71-88.

Armstrong, C. S., Guay, W. R., \& Weber, J. P. (2010). The role of information and financial reporting in corporate governance and debt contracting. Journal of Accounting and Economics, 50(2), 179-234.

Averchenkova, A., Crick, F., Kocornik-Mina, A., Leck, H., \& Surminski, S. (2015). Multinational corporations and climate adaptation-Are we asking the right questions? A review of current knowledge and a new research perspective. Grantham Research Institute on Climate Change and the Environment Working Paper, 183.

Bennett, D. C., \& Sharpe, K. E. (2014). Transnational Corporations Versus the State: The Political Economy of the Mexican Auto Industry. New Jersey: Princeton University Press.

Birkinshaw, J., \& Gibson, C. (2004). Building ambidexterity into an organization. MIT Sloan Management Review, 45(4), 47.

Birkinshaw, J., Bessant, J., \& Delbridge, R. (2007). Finding, forming, and performing: Creating networks for discontinuous innovation. California Management Review, 49(3), 67-84.

Brunninge, O., Nordqvist, M., \& Wiklund, J. (2007). Corporate governance and strategic change in SMEs: The effects of ownership, board composition and top management teams. Small Business Economics, 29(3), 295-308.

Dnishev, F., \& Alzhanova, F. (2016). Globalization of Technological Development and Opportunities for National Innovation Systems of Developing Countries. Journal of Asian Finance, Economics and Business, 3(4), 67-79.

Donaldson, T. (1996). Values in tension: Ethics away from home. Harvard Business Review, 74(5), 48.

Doz, Y. L., \& Prahalad, C. K. (1991). Managing DMNCs: A search for a new paradigm. Strategic Management Journal, 12(S1), 145-164.
Enright, M. J., (2005a). Regional management centers in the Asia-Pacific. Management International Review, 45(1), 59-82.

Frenz, M., \& letto-Gillies, G. (2009). The impact on innovation performance of different sources of knowledge: Evidence from the UK Community Innovation Survey. Research Policy, 38(7), 11251135.

Ghemawat, P. (2003). Semiglobalization and international business strategy. Journal of International Business Studies, 34(2), 138-152.

Ghemawat, P. (2007). Redefining Global Strategy. Boston: Harvard Business School Publishing, 40-64.

Ghemawat, P. (2008). Reconceptualizing International Strategy and Organization. Strategic Organization, 6(2), 195-206.

Ghemawat, P., \& Ghadar, F. (2006). Global integration $\neq$ global concentration. Industrial and Corporate Change, 15(4), 595-623.

Ghoshal, S., \& Bartlett, C. (1986). Tap your subsidiaries for global reach. Harvard Business Review, 64(6), 87-94

Haron, A. J. (2016). Standardized versus localized strategy: The role of cultural patterns in society on consumption and market research. J Account Mark, 5(151), 2-13.

Heinecke, P. (2011). Success Factors of Regional Strategies for Multinational Corporations: Appropriate Degrees of Management Autonomy and Product Adaptation. Berlin: Physica-Verlag

Hennart, J. F. (2000). Transaction Costs Theory and the Multinational Enterprise. London, U.K.: Routledge: 73-120.

Kentor, J. (2015). The growth of transnational corporate networks: 1962-1998. Journal of World-Systems Research, 11(2), 263-286.

Levitt, T. (1983). The Globalization of Markets. Harvard Business Review, 61(3), 92-102.

Markov, M. A. (2015). Internationalization of R\&D and the role of TNCs at the present stage of development of the world economy. Problems of Modern Economics, 2(54), 129-131.

Militaru, C., \& Zanfir, A. (2014). Adaptation strategies of transnational corporations at the cultural specificity of the international business environment. Knowledge Horizons. Economics, 6(2), 142.

Mom, T. J., Van Den Bosch, F. A., \& Volberda, H. W. (2009). Understanding variation in managers' ambidexterity: Investigating direct and interaction effects of formal structural and personal coordination mechanisms. Organization Science, 20(4), 812-828. 
Narayandas, D., Quelch, J., \& Swartz, G. (2000) Prepare your company for global pricing. MIT Sloan Management Review, 42(1) 61-70.

Pearce, R., \& Papanastassiou, M. (2006). To 'almost see the world': Hierarchy and strategy in Hymer's view of the multinational. International Business Review, 15(2), 151-165.

Porter, M. E., \& Kramer, M. R. (2011). Creating Shared Value. Harvard Business Review, 89(1-2), 62-77.

Prahalad, C. K., \& Hammond, A. (2002). Serving the world's poor, profitably. Harvard Business Review, 80(9), 4859.
Pries, L. (2013). New Transnational Social Spaces: International migration and transnational companies in the early twenty-first century. London: Routledge.

Rothaermel, F. T., \& Alexandre, M. T. (2009). Ambidexterity in technology sourcing: The moderating role of absorptive capacity. Organization Science, 20(4), 759-780.

Rugman, A. M. (2005). The Regional Multinationals: MNEs and 'Global' Strategic Management. Cambridge: Cambridge University Press.

Williams, C. R. (1967). Regional Management Overseas. Harvard Business Review, 45(1), 87-91. 